\title{
Genetic variation in European larch (Larix decidua Mill)
}

\author{
J Maier \\ Universität München, Lehrstuhl für Forstbotanik, Amalienstraße 52, 8000 Munich 40, Germany
}

(Received 22 February 1991; accepted 25 September 1991)

\begin{abstract}
Summary - Levels of electrophoretically demonstrable diversity of 7 allozyme loci were estimated in 7 populations representing the natural range of Larix decidua (Mill). On average the gene diversity was 0.223 and the number of alleles per locus was 2.28 . Only $5.1 \%$ of the total genetic diversity resided among populations with a mean genetic distance among populations of 0.029 . The populations could be assigned to two geographic groups, a large one containing populations from the eastern Alps as well as from Poland and Czechoslovakia and a rather restricted one with a single population from the Western Alps. The most homogeneous populations are those from eastern Europe (Poland, Sudetan region and Tatra mountains).
\end{abstract}

\section{Larix decidua / allozymes / genetic variation}

Résumé - Variation génétique du mélèze d'Europe (Larlx decldua Mill). Le niveau de diversité de 7 marqueurs génétiques a été étudié en électrophorèse pour 7 populations représentatives de la variation naturelle du Larix decidua (Mill). En moyenne, la diversité génétique était de 0,223 et le nombre d'allèles par marqueur 2,28. Seulement $5,1 \%$ de la diversité génétique totale étaient représentés dans des populations d'une distance génétique moyenne entre populations de 0,029. Les populations purent être assignées à 2 groupes géographiques, dont l'un, le plus important, comprend les populations des Alpes orientales, ainsi que celles de Pologne et de Tchécoslovaquie, alors que l'autre, plus réduit, ne comprend qu'une seule population des Alpes occidentales. Les populations les plus homogènes sont celles d'Europe orientale (Pologne, Sudètes, chaîne du Tatra).

\section{Larix decidua / diversité génétique ' marqueurs génétiques}




\section{INTRODUCTION}

Larix decidua Mill has its natural range restricted to four distinct areas of Central and eastern Europe: the Alps, the Sudetan region, the Tatra Mountains and scattered throughout Poland (fig 1). It has been the subject of both numerous provenance experiments (Cieslar, 1899, 1914; Varma, 1949; Leibundgut, 1959; Barnes, 1977; Giertych, 1979; Schober, 1977, 1985) and other studies concerning phenotypic traits (Bouvarel and Lemoine, 1958; Gathy, 1959; Schreiber, 1960, 1961, 1963; Kral, 1966, 1967; Simak, 1967; Lang, 1976; Leibundgut, 1985). These investigations underline the fact that European larch is a highly variable species. Allozyme surveys estimating gene diversity among populations are not known for Larix decidua, but within the genus Larix for $L$ laricinia (Che- liak et al, 1988) and for L occidentalis (Fins and Seeb, 1986). However, for $L$ decidua from Poland segregation studies of allozyme loci are already available (Mejnartowicz and Bergmann, 1975; Kosinski and Szmidt, 1984; Lewandowski and Mejnartowicz, 1990a, b, 1991). In this study seeds from provenances covering all four parts of the range of European larch were analysed by gel electrophoresis. The genetic interpretation of six enzyme gene markers as well as the calculation of genetic differentiation parameters will be presented.

\section{MATERIALS AND METHODS}

Geographic location and background information for the seven populations of Larix decidua are given in figure 1 and table 1 . Bulked seed samples, where seeds from several trees were pooled, as well as seed lots from individual trees

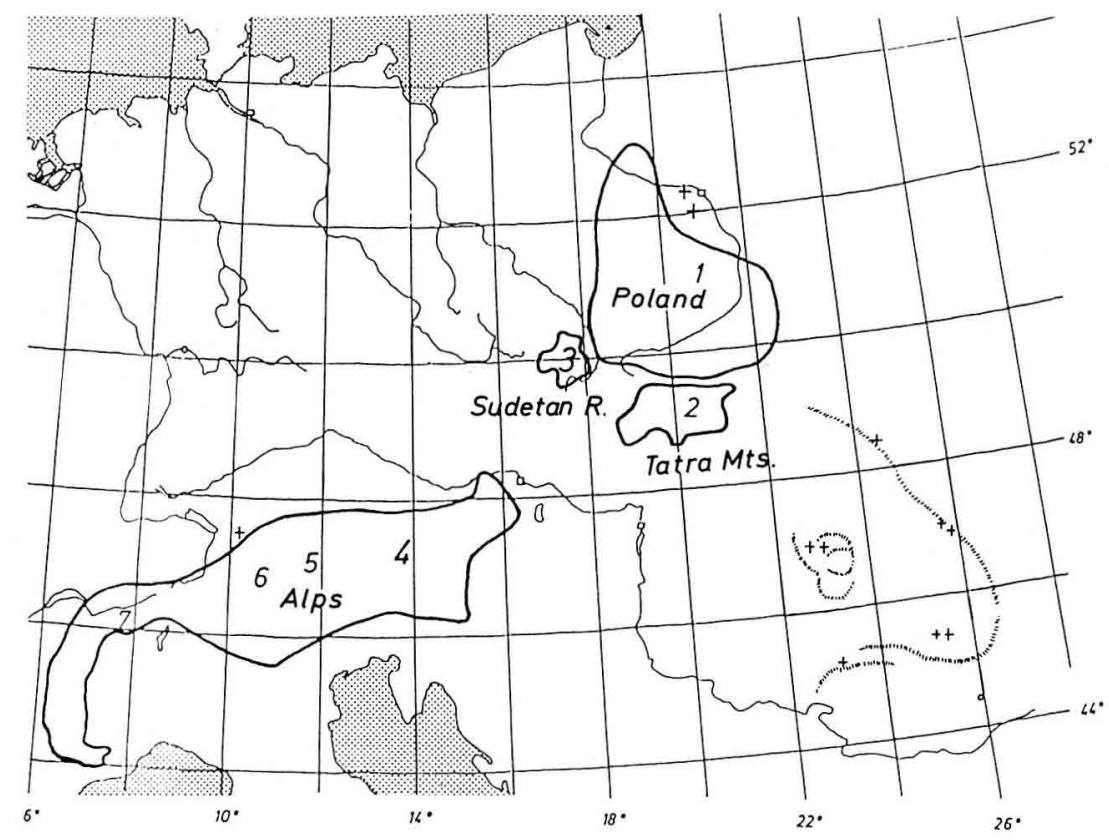

Fig 1. Natural range of Larix decidua (Mill). Numbers 1-7 refer to populations in table I (redrawn from Schober, 1977). 
Table I. List of provenances under study.

\begin{tabular}{|c|c|c|c|c|c|c|}
\hline No & Population & Country & $\begin{array}{l}\text { Altitude } \\
(m)\end{array}$ & $\begin{array}{l}\text { Seed } \\
\text { type* }\end{array}$ & \multicolumn{2}{|c|}{$\begin{array}{c}\text { No of troes/ } \\
\text { seeds analysed }\end{array}$} \\
\hline $\begin{array}{l}1 \\
2 \\
3 \\
4 \\
5 \\
6 \\
7\end{array}$ & $\begin{array}{l}\text { Lysa Gora } \\
\text { Smokovec } \\
\text { Sudetan } \\
\text { Eastern Alps } \\
\text { Pfitsch } \\
\text { Wintschgau } \\
\text { Simplon }\end{array}$ & $\begin{array}{l}\text { Poland } \\
\text { CFSR } \\
\text { CFSR } \\
\text { Austria } \\
\text { Italy } \\
\text { Italy } \\
\text { Switzerland }\end{array}$ & $\begin{array}{r}300 \\
1200 \\
300-650 \\
900-1700 \\
1100-1900 \\
900-1300 \\
1400-1500\end{array}$ & $\begin{array}{l}b \\
s \\
b \\
b \\
s \\
b \\
s\end{array}$ & $\begin{array}{l}30 \\
56 \\
23\end{array}$ & $\begin{array}{l}144 \\
\\
136 \\
50 \\
\\
144\end{array}$ \\
\hline
\end{tabular}

- $\mathrm{b}=$ bulked seed sample, $\mathrm{s}=$ single tree seed lots.

were sampled. Both of them originate from indigenous populations; the former were provided by forest research stations in Poland, Czechoslovakia, and Austria, and the latter were collected by us. Seeds from many small stands from the Sudetan region as well as from a limited area in the eastern Alps were grouped, respectively.

Electrophoretic analysis was carried out on the endosperm. Between 50 and 144 have been examined for the bulk provenance collections. For the provenances with single tree seeds, six endosperms per tree were analysed. Horizontal starch gel electrophoresis was carried out to separate isozymes for six enzyme systems:

$\begin{array}{ll}\text { GDH } & \text { (EC 1.4.1.3) } \\ \text { IDH } & \text { (EC 1.1.1.42) } \\ \text { G6PDH } & \text { (EC 1.1.1.49) } \\ \text { 6PGDH } & \text { (EC 1.1.1.43) } \\ \text { SKDH } & \text { (EC 1.1.1.25) } \\ \text { MDH } & \text { (EC 1.1.1.37) }\end{array}$

Details of gel and electrophoresis buffer and staining mixtures were taken from Conkle et al (1982) and from Müller-Starck (personal communication). Enzyme band phenotypes, evidence from gametic segregation ratios and close analogy to results from other isozyme investigations in larch (Cheliak and Pitel, 1985; Fins and Seeb, 1986; Lewandowski and Mejnartowicz, 1990a, b; Ying and Morgenstern, 1990) were the basis for genetic interpretation of the zymograms. Capital letters refer to gene loci, number 1 being assigned to the most mobile band at any locus. A locus was considered polymorphic if more than one allele was observed, regardless of allelic frequencies.

Nei's (1972) genetic distance (D) was used to quantify the degree of differentiation among populations. Cluster analysis, using the UPGMA-method, was performed with SPSS (Norusis, 1986) on the matrix of Nei's genetic distances. Gene diversity analysis was calculated according to Nei (1973). A measure of total gene diversity is $H_{T}=1-\Sigma p_{i}^{2}$, where $p^{2}$ is the mean frequency of the $i$ th of $k$ alleles. $H_{T}$ is partitioned in $H_{T}=H_{S}+D_{S T}$, where $H_{S}$ and $D_{S T}$ are average gene diversities within and among populations, respectively. $G_{S T}$ is the proportion of interpopulation gene diversity $H_{T}$.

\section{RESULTS}

IDH and GDH were found to be monomorphic. No variation was observed for the allozyme encoded by these loci (fig $2 a, b$ ). Two zones of activity were observed on gels stained for G6PDH. The lower zone stained inconsistently and was therefore not scored. The fastest migration zone exhibits 3 bands differing in mobility (fig 2c). Thus, 1 locus with 3 alleles was postulated. A heavily stained zone with 2 single- 


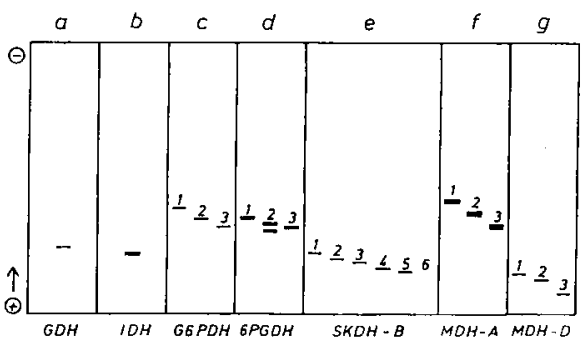

Fig 2. Zymograms with locus designations and allozyme numbers for seven loci.

banded and 1 double-banded phenotype was found for 6PGDH, suggesting a 3 allele locus (fig 2d). Gametophytes scored for SKDH showed 2 zones of activity. The faster zone was unreliably stained and could not be considered. The more cathodal zone exhibits 5 bands differing in mobility and staining intensity. In addition, a null allele was observed. Thus, this zone was interpreted as 1 locus with 6 alleles (fig 2e). A 5 zone banding pattern, inferred as four loci and an interlocus heterodimer, was recorded for $\mathrm{MDH}$. On account of poor band resolution, $\mathrm{MDH}-\mathrm{B}$ and $\mathrm{MDH}-\mathrm{C}$ were not further analysed. Both MDH-A and MDH-D performed 3 bands suggesting 2 loci with 3 alleles each (fig $2 f$ and $2 \mathrm{~g}$ ).

Allele frequencies are given in table II. When comparing gene frequencies of the 7 populations, qualitative differences occur only in rare variants. The same allele pre-

Table II. Allele frequencies of seven provenances.

\begin{tabular}{|c|c|c|c|c|c|c|c|c|}
\hline & & $\begin{array}{l}\text { Lysa } \\
\text { Gora }\end{array}$ & $\begin{array}{c}\text { Smoko- } \\
\text { vec }\end{array}$ & $\begin{array}{l}\text { Po } \\
\text { Sude- } \\
\tan \end{array}$ & $\begin{array}{r}\text { ations } \\
E- \\
\text { Alps }\end{array}$ & Pfitsch & $\begin{array}{l}\text { Vint- } \\
\text { gau }\end{array}$ & Simplon \\
\hline \multicolumn{9}{|l|}{ Allele } \\
\hline G6PDH & $\begin{array}{l}y-1 \\
-2 \\
-3\end{array}$ & $\begin{array}{l}0.319 \\
0.500 \\
0.181\end{array}$ & $\begin{array}{l}0.256 \\
0.611 \\
0.133\end{array}$ & $\begin{array}{l}0.320 \\
0.524 \\
0.156\end{array}$ & $\begin{array}{l}0.429 \\
0.469 \\
0.102\end{array}$ & $\begin{array}{l}0.385 \\
0.375 \\
0.240\end{array}$ & $\begin{array}{l}0.445 \\
0.444 \\
0.111\end{array}$ & $\begin{array}{l}0.123 \\
0.833 \\
0.044\end{array}$ \\
\hline 6PGD & $\begin{array}{r}f-1 \\
-2 \\
-3\end{array}$ & $\begin{array}{l}0.069 \\
0.171 \\
0.760\end{array}$ & $\begin{array}{l}0.067 \\
0.139 \\
0.794\end{array}$ & $\begin{array}{l}0.072 \\
0.231 \\
0.697\end{array}$ & $\begin{array}{l}0.182 \\
0.091 \\
0.727\end{array}$ & $\begin{array}{l}0.027 \\
0.080 \\
0.893\end{array}$ & $\begin{array}{l}0.201 \\
0.167 \\
0.632\end{array}$ & $\begin{array}{l}0.349 \\
0.007 \\
0.644\end{array}$ \\
\hline SKDH & $\begin{array}{l}-1 \\
-2 \\
-3 \\
-4 \\
-5 \\
-6\end{array}$ & $\begin{array}{l}0.049 \\
0.090 \\
0.153 \\
0.652 \\
0.021 \\
0.035\end{array}$ & $\begin{array}{c}- \\
0.183 \\
0.222 \\
0.545 \\
0.033 \\
0.017\end{array}$ & $\begin{array}{c}0.007 \\
0.171 \\
0.173 \\
0.642 \\
- \\
0.007\end{array}$ & $\begin{array}{c}- \\
0.279 \\
0.186 \\
0.512 \\
0.023 \\
-\end{array}$ & $\begin{array}{l}- \\
0.289 \\
0.169 \\
0.535 \\
\overline{0} \\
0.007\end{array}$ & $\begin{array}{c}- \\
0.270 \\
0.042 \\
0.681 \\
- \\
0.007\end{array}$ & $\begin{array}{c}- \\
0.058 \\
0.008 \\
0.934 \\
- \\
-\end{array}$ \\
\hline MDH & $\begin{array}{l}-A 1 \\
-A 2 \\
-A 3\end{array}$ & $\begin{array}{c}0.069 \\
0.931 \\
-\end{array}$ & $\begin{array}{l}0.100 \\
0.883 \\
0.017\end{array}$ & $\begin{array}{c}0.014 \\
0.986 \\
-\end{array}$ & $\begin{array}{c}- \\
1.000 \\
-\end{array}$ & $\begin{array}{c}-\overline{000} \\
-\end{array}$ & $\begin{array}{c}\overline{1.000} \\
-\end{array}$ & $\frac{-}{1.000}$ \\
\hline $\mathrm{MDH}$ & $\begin{array}{l}-\mathrm{D} 1 \\
-\mathrm{D} 2 \\
-\mathrm{D} 3\end{array}$ & $\frac{\overline{-}}{1.000}$ & $\frac{-}{1.000}$ & $\begin{array}{l}0.007 \\
0.971 \\
0.022\end{array}$ & $\begin{array}{l}0.040 \\
0.900 \\
0.060\end{array}$ & $\begin{array}{c}- \\
1.000 \\
-\end{array}$ & $\begin{array}{l}0.014 \\
0.972 \\
0.014\end{array}$ & $\begin{array}{l}\overline{0} \\
0.042 \\
0.058\end{array}$ \\
\hline
\end{tabular}


vails at every locus in all populations with the exception of the G6PDH. The frequency of the G6PDH-1 allele exceeds that of G6PDH-2 at the provenances Pfitsch and Vintschgau, while for the rest the opposite is true.

The estimates of genetic distances for all combinations of provenances averaged over the 7 loci are presented in table III. The distances (average 0.029 ) are lowest among the eastern European samples from Poland, the Sudetan region and the Tatra Mts (0.004-0.009). The Simplon population appeared to be the most divergent from all other populations with genetic distances rising up to 0.099. All alpine samples have relatively large average distances between each other.

Figure 3 shows the dendrogram resulting from UPGMA clustering based on NEl's genetic distance. The general analysis showed that two large groups were delineated. The Simplon material from the western Alps is clearly distinct from the other 6 populations. In this cluster containing 6 populations the 3 provenances from eastern Europe form a relatively homogeneous sub-cluster which is slightly different from the Alpine provenances.

Gene diversity per locus varies widely from 0.027 at MDH-A to 0.653 at G6PDH (table IV). The mean heterozygosity per population ranges from 0.140 in the Sim-

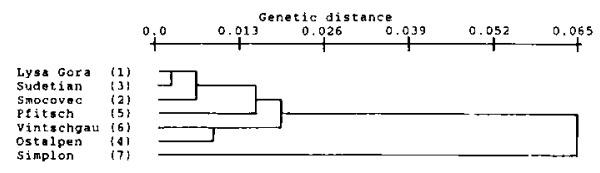

Fig 3. UPGMA cluster analysis of NEl's genetic distance.

plon population to 0.260 in the Ostalpen population with a mean of 0.223 over all (E-Alps) populations. The mean number of alleles per locus was 2.28 with a minimum of 2.0 in the Pfitsch and Simplon populations and a maximum of 2.6 in the Sudetan region. On the average, $94.9 \%(\mathrm{Hs} / \mathrm{Hr} \times$ $100 \%$ ) of the gene diversity resided within stands and $5.1 \%$ among stands $\left(\mathrm{G}_{\mathrm{ST}} \times\right.$ $100 \%$, table V).

\section{DISCUSSION}

Monomorphic loci at GDH are reported for L laricina (Cheliak and Pitel, 1985; Ying and Morgenstern, 1990) and at IDH for L laricina (Cheliak and Pitel, 1985) as well as for $L$ occidentalis (Fins and Seeb, 1986). Lewandowski and Mejnartowicz (1990a) found these 2 enzyme systems controlled by 1 locus with 1 dominating allele and 2 rare alleles each. Corresponding

Table III. Estimates of genetic distances based on data from seven loci.

\begin{tabular}{|c|c|c|c|c|c|c|}
\hline & $\begin{array}{l}\text { Lysa } \\
\text { Gora }\end{array}$ & Smokovec & Sudetan & $E-A / p s$ & Pfitsch & $\begin{array}{c}\text { Vintsch- } \\
\text { gau }\end{array}$ \\
\hline Smokovec & 0.008 & & & & & \\
\hline Sudetan & 0.004 & 0.009 & & & & \\
\hline E-Alps & 0.018 & 0.018 & 0.013 & & & \\
\hline Pfitsch & 0.016 & 0.019 & 0.017 & 0.013 & & \\
\hline Vintschgau & 0.017 & 0.029 & 0.011 & 0.010 & 0.024 & \\
\hline Simplon & 0.052 & 0.056 & 0.052 & 0.099 & 0.054 & 0.070 \\
\hline
\end{tabular}


Table IV. Population gene diversity.

\begin{tabular}{|c|c|c|c|c|c|c|c|}
\hline \multirow[t]{2}{*}{ Populations } & \multicolumn{6}{|c|}{ Gene diversity } & \multirow{2}{*}{$\begin{array}{c}\text { No } \\
\text { of alleles } \\
\text { per locus }\end{array}$} \\
\hline & $G 6 P D H$ & 6PGDH & $S K D H$ & $M D H-A$ & $M D H-D$ & mean $^{*}$ & \\
\hline Lysa Gora & 0.615 & 0.388 & 0.538 & 0.128 & 0.000 & 0.238 & 2.4 \\
\hline Smokovec & 0.543 & 0.345 & 0.618 & 0.210 & 0.000 & 0.245 & 2.4 \\
\hline Sudetan & 0.598 & 0.455 & 0.528 & 0.027 & 0.056 & 0.237 & 2.6 \\
\hline E-Alps & 0.585 & 0.430 & 0.624 & 0.000 & 0.184 & 0.260 & 2.3 \\
\hline Pfitsch & 0.653 & 0.195 & 0.594 & 0.000 & 0.000 & 0.206 & 2.0 \\
\hline Vintschgau & 0.592 & 0.532 & 0.461 & 0.000 & 0.054 & 0.234 & 2.3 \\
\hline Simplon & 0.289 & 0.463 & 0.124 & 0.000 & 0.109 & 0.140 & 2.0 \\
\hline
\end{tabular}

* = calculated over 7 loci (including 2 monomorphic loci).

Table V. Gene diversity analysis.

\begin{tabular}{lcccc}
\hline Locus & $\begin{array}{c}\text { Total } \\
\left(\mathrm{H}_{\mathrm{T}}\right)\end{array}$ & $\begin{array}{c}\text { Within } \\
\text { populations } \\
\left(\mathrm{H}_{\mathrm{S}}\right)\end{array}$ & $\begin{array}{c}\text { Among } \\
\text { populations } \\
\left(\mathrm{D}_{\mathrm{ST}}\right)\end{array}$ & $\begin{array}{c}\text { Proportion of } \\
\text { among-population } \\
\text { differentiation } \\
\left(\mathrm{G}_{\mathrm{ST}}\right)\end{array}$ \\
\hline G6PDH & 0.588 & 0.553 & 0.035 & 0.060 \\
6PGDH & 0.425 & 0.401 & 0.024 & 0.056 \\
SKDH & 0.521 & 0.498 & 0.023 & 0.044 \\
MDH-A & 0.054 & 0.052 & 0.002 & 0.037 \\
MDH-D & 0.060 & 0.057 & 0.003 & 0.050 \\
mean* & 0.235 & 0.223 & 0.012 & 0.051 \\
\hline
\end{tabular}

* calculated over 7 loci (including 2 monomorphic loci).

to the present results a 3-allele locus at G6PDH was found for $L$ decidua (Lewandowski and Mejnartowicz, 1990a) and for L laricina (Cheliak and Pitel, 1985). At SKDH Lewandowski and Mejnartowicz (1990a) detected 1 locus with four alleles. Further studies of SKDH in Larix have been done on one single clone of both European and Japanese larch (Bergmann and Ruetz, 1987). The finding of four MDH loci in many other conifers (Wheeler et al,
1983; Cheliak and Pitel, 1985; Yeh et al, 1985; Fins and Seeb, 1986; Ernst et al, 1987; Merkle and Adams, 1987; Bergmann, 1988; El-Kassaby, 1989; Lewandowski and Mejnartowicz, 1990a) are in agreement with the present results. For $L$ decidua Lewandowski and Mejnartowicz (1990a) observed at MDH1 (MDH-A) and MDH4 (MDH-D) a deviating number of alleles. For Polish larch however, the postulation of a monomorphic locus at MDH-D 
(table II: Population Lysa Gora) is consistent with observations by Lewandowski and Mejnartowicz (1990b). This indicates that deviation in number of alleles per locus at GDH, IDH, MDH and SKDH in present results compared to those by Lewandowski and Mejnartowicz (1990a) may be due to different populations investigated. At 6PGDH one (Cheliak and Pitel, 1985) or two (Fins and Seeb, 1986) polymorphic loci had been reported for $L$ laricina and $L$ occidentalis, respectively.

Levels of genetic distances and gene diversity among provenances of $L$ decidua reveal very similar average values for $L$ laricina (Cheliak et al, 1988); however, the average number of alleles per locus is higher in $L$ decidua. On the other hand, L occidentalis (Fins and Seeb, 1986) differs considerably from $L$ laricina and $L d e$ cidua by relatively low genetic variability as well as genetic distances among populations. This is surprising considering the extent of the species ranges. $L$ laricina expands continent-wide, while $L$ decidua and $L$ occidentalis are localized in restricted regions. Fins and Seeb (1986) suggest that low genic differentiation and diversity among stands of western larch may be the resuit of isolated refugia during Pleistocene glaciation and founder effects after fires. On the other hand, with regard to the relatively low number of enzyme systems asseyed, the results for $L$ decidua should be interpreted carefully. Nevertheless, a substantial difference in gene diversity between $L$ decidua and $L$ occidentalis remains.

Genetic variability of $L$ decidua evaluated for two Polish stands and for a seed orchard in Poland was considered to be low (Mejnartowicz and Bergmann, 1975; Kosinski and Szmidt, 1984). In this study no obvious low gene diversity in the Polish population (Lysa Gora) was found.

Nei's (1972) genetic distance indicated relatively large genetic differences among larch populations. The isolated position of the Simplon stand in genetic distance matrix and in cluster analysis may be due to the relatively small sample size (23 trees). However, cluster analysis derived from monoterpene data of larch seedlings (unpublished data) exhibits full correspondence to the isozyme results. In addition, provenance experiments support the results from both the isoenzyme and resin oil analyses. Substantial differences in growth rate between western and eastern Alpine provenances have been pointed out (Schober, 1977, 1985). Considerable amounts of differentiation in several traits among provenances resulted in several authors speaking of alpine larch races and/or ecotypes (Wettstein, 1946; Rubner, 1954; Mayer, 1961; Kral, 1967; Leibundgut, 1985). In contrast, the eastern European provenances form a quite uniform group in respect to larch canker susceptibility and growth rate (Schober, 1977, 1985). According to these and present results, the larches from Poland, the Tatra Mts and the Sudetan region may be regarded as one single race.

\section{ACKNOWLEDGMENTS}

I am indebted to $P$ Schütt and $G$ Aas for reviewing the manuscript. I also wish to thank JM Vincent, A Stapf and R Schacher for linguistic advice and $R$ Vogtmann for drawing figures. This study was financially supported by a grant from the Deutsche Forschungsgemeinschaft, Bad Godesberg.

\section{REFERENCES}

Barnes BV (1977) The International Larch Provenance Test in southeastern Michigan, USA. Silvae Genet 26, 145-148

Bergmann F (1988) Untersuchungen der genetischen Differenzierung der Fichte in den Seetaler Alpen an Enzym-Genloci. Forum- 
Genetik-Wald-Forstwirtschaft. 5. Arbeitstagung, Innsbruck, 1988. Schriftenr Forstl Bundesversuchsanst Wien 28, 163-172

Bergmann F, Ruetz W (1987) Identifizierung von Hybridlärchensaatgut aus Samenplantagen mit Hilfe eines Isoenzym-Markers. Silvae Genet 36, 102-105

Bouvarel P, Lemoine M (1958) Races de mélèze et grosseur des graines. Rev For Fr 5 , 348-350

Cheliak WM, Pitel JA (1985) Inheritance and linkage of allozymes in Larix laricina. Silvae Genet 34, 142-147

Cheliak WM, Wang J, Pitel JA (1988) Population structure and genic diversity in tamarack, Larix laricina (Du Roi) K Koch. Can J For Res 18, 1318-1324

Cieslar A (1989) Neues aus dem Gebiete der Forstlichen Zuchtwahl. Centrabl Gesamte Forstwes 5, 49-74, 99-117

Cieslar A (1914) Studien über die Alpen- und Sudetenlärche. Centrabl Gesamte Forstwes 40, 171-184

Conkle MT, Hodgskiss PD, Nunnally LB, Hunter SC (1982) Starch Gel Electrophoresis of Conifer Seeds: A Laboratory Manual. General Technical Report PSW - 64. Berkely, CA: Pacific Southwest Forest and Range Experiment Station, Forest Service, US Department of Agriculture

El-Kassaby YA (1981) Genetic interpretation of malate dehydrogenase isozymes in some conifer species. $J$ Hered 72, 451-452

Ernst SG, Keathley DE, Hanover JW (1987) Inheritance of isozymes in seed and bud tissues of blue and Engelmann spruce. Genome 29, 239-246

Fins L, Seeb LW (1986) Genetic variation in allozymes of Western Larch. Can J For Res 16, 1013-1018

Gathy P (1959) Contribution à l'étude des races du mélèze d'Europe (Larix decidua Mill). Trav Stat Rech des Eaux et Forêts, Ser B, No 22

Giertych M (1979) Summary of results on European Larch (Larix decidua Mill) height growth in the IUFRO 1944 provenance experiment. Silvae Genet 28, 244-256

Kosinski G, Szmidt AE (1984) Isoelectric focusing of acid phosphatase and esterase from
European Larch (Larix decidua). Arbor Kornickie 29, 73-80

Kral F (1966) Der osmotische Wert des Nadelpreßsaftes von Lärchenherkünften als Mittel zur Frühdiagnose ihrer Trockenresistenz. Forstpflanzen-Forstsamen 4

Kral F (1967) Untersuchungen zur Physiologie und Ökologie des Wasserhaushalts von Lärchenrassen. Ber Deutsch Bot Ges 80, 145154

Lang KJ (1976) Unterschiede in der Monoterpenzusammensetzung des Harzes einjähriger Lärchenzweige. Forstwiss $\mathrm{Cb} / 95,142-$ 147

Leibundgut H (1959) Untersuchungen über europäische Lärchen verschiedener Herkunft. 2. Mitteilung: Der jährliche Verlauf des Höhenwachstums. Schweiz Ztschr Forstwes 110, 309-314

Leibundgut $H$ (1985) Beiträge zur Unterscheidung von Lärchenrassen. Verh Zool-Bot Ges Österr 123, 293-301

Lewandowski A, Mejnartowicz L (1990a) Inheritance of allozymes in Larix decidua Mill. Silvae Genet 39, 184-188

Lewandowski A, Mejnartowicz L (1990b) Genetic control of Polish larch [Larix decidua subsp polonica (Racib) Domin] malate dehydrogenase (EC 1.1.1.37). Genet Polon 31, 217-221

Lewandowski A, Mejnartowicz L (1991) Linkage analysis of allozyme loci in Polish larch (Larix decidua subsp polonica (Racib) (Domin). Hereditas 114, 107-109

Mayer H (1961) Waldbauliche Beiträge zur genetischen Beurteilung der Lärche. Forstwiss $\mathrm{Cb} / 80,29-48$

Mejnartowicz L, Bergmann F (1975) Genetic studies of European Larch (Larix decidua Mill) employing isoenzyme polymorphism. Genet Polon 16, 29-35

Merkle SA, Adams WT (1987) Patterns of allozyme variation within and among Douglas-fir breeding zones in southwest Oregon. Can J For Res 17, 402-407

Nei M (1972) Genetic distance between populations. Am Nat 106, 283-292

Nei M (1973) Analysis of gene diversity in subdivided populations. Proc Natl Acad Sci USA $70,3321-3323$ 
Norusis MJ (1986) SPSS/PC+ for the IBM PCI XT/AT. Advanced Statistics. SPSS Inc, Chicago

Rubner K (1954) Zur Frage der Entstehung der alpinen Lärchenrassen. Ztschr f Forstgenet $u$ Forstpflanzenzüchtung 3, 49-51

Schober R (1977) Vom II. Internationalen Lärchenkerkunftsversuch. Ein Beitrag zur Lärchenherkunftsfrage. Schriftenr Forstl Fak Univ Göttingen u Mitt Niedersächs Forstl Versuchsanst 49

Schober R (1985) Neue Ergebnisse des II. Internationalen Lärchenherkunftsversuchs von 1958/1959 nach Aufnahmen von Teilversuchen in 11 europäischen Ländern und der USA. Schriftenr Forstl Fak Univ Göttingen u Mitt Niedersächs Forstl Versuchsanst 83

Schreiber M (1960) Zur physiologischen Reaktionsweise von Provenienzen der europäischen Lärche (Larix decidua Mill), der Japanlärche (Larix leptolepis Gord) und der sibirischen Lärche (Larix sibirica Ledeb) auf gleiche Umweltbedingungen. $C b /$ Ges Forstwes 77, 18-26

Schreiber M (1961) Zur physiologischen Reaktionsweise von Provenienzen der Europäischen Lärche (Larix decidua Mili), der Japanlärche (Larix leptolepis Gord) und der sibirischen Lärche (Larix sibirica Lebed) auf gleiche Umweltbedingungen. III. Neuere Un- tersuchungen. Cbl Ges Forstwes 78 1-17, 93-105

Schreiber M (1963) Über neuere Ergebnisse auf dem Gebiet der Lärchenrassenbiologie. Schweiz Z Forstwes 17, 44-74

Simak M (1967) Seed weight of larch from different provenances (Larix decidua Mill). Stud For Suec 57

Varma JC (1949) A study of the variation of morphological characters within special reforence to European Larch of different provenances (Larix decidua Mill) Forestry 23, 2030

Wettstein VW (1946) Alpenlärchenrassen. Der Züchter 17, 40-44

Wheeler NC, Guries RP, O'Malley DM (1983) Biosystematic of the genus Pinus, subsection contortae. Biochem Syst Ecol 11, 333-340

Yeh FC, Cheliak WM, Danckik BP, Illingsworth K, Trust DC, Pryhitka BA (1985) Population differentiation in Lodgepole Pine, Pinus contorta ssp latifolia: a discriminant analysis of allozyme variation. Can J Genet Cytol 27 , 210-218

Ying L, Morgenstern EK (1990) Inheritance and linkage relationships of some isozymes of Larix laricina in New Brunswick, Canada. Silvae Genet 39, 245-251 